\title{
PEAT DEPOSITS IN THE UNITED STATES AND THEIR CLASSIFICATION
}

\author{
ALFRED P. DACHNOWSKI \\ Bureau of Plant Industry, Uniled States Department of Agriculture
}

Received for publication November 12, 1920

AREA AND GENERAL DISTRIBUTION

The peat deposits in the United States of both fresh-water and salt-water origin have been variously estimated in regard to area, location, and character.

The report of the Commissioner of the General Land Office for 1907 gives $65,582,503$ acres as the area of swamp land, claims for which had been approved and certified under various acts.

From Wright's results of a canvass made in the same year by the Office . of Experiment Stations (21) it appears that alone in the eastern portion of the United States there are 77,000,000 acres of swamp and overflowed land.

In Senate Document No. 443 of the sixtieth Congress, first session, 1908, the estimate by Elliott is placed at 79,005,023 acres in the several states, exclusive of the coast lands which are overflowed by tidewater. They are listed as permanent swamp, wet grazing land, periodically overflowed land and periodically swampy land; this classification represents approximately the relative agricultural value of the land as affected by surface water conditions (20).

Davis (8) finds that the total area of peat land is nearly 140,000 square miles. Of this 8 per cent, or about 11,200 square miles, is assumed to be peat deposits of good quality, averaging at least 9 feet in thickness.

McCrory (12), summarizing the drainage movement in the United States, gives as the most reliable information obtainable concerning the undeveloped area of swamp and wet lands a total of $102,000,000$ acres, of which $66,900,000$ acres are swamp, 31,500,000 acres are periodically overflowed and 4,400,000 acres are tidal marsh.

According to Baker and Strong (1) only about $60,000,000$ acres are swamp and other wet lands, and practically none of this land, which would make $1,000,000$ farms of 60 acres each, is reported to be available for settlement at present.

More recently a report has been issued upon the unused lands in this country, as House Document No. 262, Sixty-sixth Congress (10). The document gives the possible projects which are available in the various states for development. The data include acreage of swamp land, cut-over land, wet grazing land, 
overflow land, and periodical swamp land. In distribution, acreage and classification House Document No. 262 of 1919 does not differ essentially from the report of 1908 by Elliott cited above.

From this brief summary it is obvious that the estimates of the actual areas of swamp and overflow lands are quite unlike; they differ still more widely when an attempt is made to distinguish the acreage which more properly constitutes workable peat deposits, and the percentage that is utilized at present for agricultural and other purposes in the different parts of the country.

As to distribution, the several authors agree more or less that the areas of peat accumulation may be assigned to two or three partly geographic regions which express the chief differences in climate, in surface vegetation, and in topography, especially those which are the results of glacial action. The deposits located in the northern region (I) may, therefore, be divided into those of the northeastern states (a), and the Lake states (b), while those in the southern or Atlantic coastal region (II) would include the Mississippi River bottoms and other river bottoms and terraces of the Coastal Plain of the South (c) and of the Gulf States with their adjoining territory (d). The known workable deposits in the Pacific coast region (III) occur in the tule lands of California and in the basins and rivers of Washington and Oregon.

The classification and acreage in table 1 is that of Elliott (20) and is reproduced here in a form to indicate the three general regional divisions.

\section{GENERAL CHARACTERISTICS OF PEAT DEPOSITS}

For diagnostic and systematic purposes as well as for other lines of work in agriculture and in the industries a full knowledge of the acreage, location and of the development and structure of workable peat deposits will naturally be of the greatest importance. As the life history of every deposit can now be studied without difficulty, provided the different layers of peat material are known, undoubtedly all our peat-land studies will gain in much needed conformity and accuracy.

Progress in peat investigations has been severely checked by the widespread use of such terms as muck, overflowed land, swampy land, wet land and others. The same error that has caused serious difficulties in the establishment of types of peat material has resulted in the lack of an adequate classification of peat deposits conforming with scientific viewpoints. Undoubtedly the adherence to composite terms unqualified in their meaning, is in part the reason why the structural features of peat deposits have been completely overlooked in this country and why thorough research in this direction has been delayed. A somewhat more critical attitude would long ago have revealed the fact that peat deposits are essentially a product of the movement of plant populations; that they have a characteristic development and structure which is related to particular habitat conditions. This concept has been discussed in detail elsewhere. It will suffice to summarize here the several : 
TABLE 1

Classification of unreclaimed swamp and overflowed land*

\begin{tabular}{|c|c|c|c|c|c|c|}
\hline $\begin{array}{l}\text { DI:- } \\
\text { GrovAl } \\
\text { DIVI- } \\
\text { gION }\end{array}$ & STATES & $\begin{array}{c}\text { PERYANENT } \\
\text { SWAKP }\end{array}$ & $\begin{array}{c}\text { WET ORAZTNO } \\
\text { LAND }\end{array}$ & \begin{tabular}{|} 
PERIODICALLX \\
OVERTLOWED
\end{tabular} & $\begin{array}{c}\text { PERIODICALLY } \\
\text { SWAMPY }\end{array}$ & Total \\
\hline & & acres & acres & acres & acres & acres \\
\hline IId & Alabama . .......... & 900,000 & 59,200 & 520,000 & & $1,479,200$ \\
\hline IId & Arkansas. . . . . . . . . & $5,200,000$ & 50,000 & 531,000 & 131,300 & $5,912,300$ \\
\hline III & California . . . . . . . & $1,000,000$ & $1,000,000$ & $1,420,000$ & & $3,420,000$ \\
\hline $\mathbf{I a}$ & Connecticut. & & 10,000 & 20,000 & & 30,000 \\
\hline IIc & Delaware.......... & 50,000 & 50,000 & 27,000 & 200 & 127,200 \\
\hline IIc & Florida . . . . . . . . . & $18,000,000$ & & $1,000,000$ & 800,000 & $19,800,000$ \\
\hline IIc & Georgia. & $1,000,000$ & & $1,000,000$ & 700,000 & $2,700,000$ \\
\hline Ib & Illinois. .... & 25,000 & 500,000 & 400,000 & & 925,000 \\
\hline Ib & Indiana . . & 15,000 & 100,000 & 500,000 & 10,000 & 625,000 \\
\hline Ib & Iowa.... & 300,000 & 200,000 & 350,000 & 80,500 & 930,500 \\
\hline & Kansas. . & & 59,380 & 300,000 & & 359,380 \\
\hline & Kentucky ........... & & 100,000 & 300,000 & 44,600 & 444,600 \\
\hline IId & Louisiana......... & $9,000,000$ & & $1,196,605$ & & $10,196,605$ \\
\hline IIc & Maryland ....... & 100,000 & & 92,000 & . & 192,000 \\
\hline Ia & Maine. . . . . . . . . & 156,520 & & & & 156,520 \\
\hline Ia & Massachusetts . . . . & 20,000 & & 39,500 & & 59,500 \\
\hline Ib & Michigan. . . . . . . . & $2,000,000$ & 947,439 & & & $2,947,439$ \\
\hline Ib & Minnesota. . & $3,048,000$ & $2,000,000$ & & 784,308 & $5,832,208$ \\
\hline IId & Mississippi. . & $3,000,000$ & & $2,760,200$ & & $5,760,200$ \\
\hline & Missouri... & $1,000,000$ & & $1,439,600$ & & $2,439,600$ \\
\hline & Nebraska....... & & 100,000 & 412,100 & & 512,100 \\
\hline Ia & New Hampshire. & 5,000 & & 7,700 & & 12,700 \\
\hline Ia & New Jersey. . . . . & 326,400 & & & & 326,400 \\
\hline Ia & New York. & 100,000 & 100,000 & 329,100 & & 529,100 \\
\hline IIc & North Carolina. . & $1,000,000$ & 500,000 & 500,000 & 748,160 & $2,748,160$ \\
\hline & North Dakota. & 50,000 & 50,000 & 50,000 & 50,000 & 200,000 \\
\hline Ib & Ohio....... & & & $\begin{array}{r}100,000 \\
31,500\end{array}$ & 55,047 & $\begin{array}{r}155,047 \\
31,500\end{array}$ \\
\hline III & $\mathrm{O}$ & 254,000 & & & & 254,000 \\
\hline Ib & Pennsylvania. & & & 50,000 & & 50,000 \\
\hline Ia & Rhode Island . . & & & 6,000 & 2,064 & 8,064 \\
\hline IIc & South Carolina. & $1,500,000$ & & 622,120 & $1,000,000$ & $3,122,120$ \\
\hline & South Dakota... & 100,000 & & 511,480 & & 611,480 \\
\hline & Tennessee...$\ldots \ldots$ & 639,600 & & & & 639,600 \\
\hline IId & Texas..... & $1,240,000$ & $1,000,000$ & & & $2,240,000$ \\
\hline Ia & Vermont & 15,000 & & 8,000 & & 23,000 \\
\hline IIc & Virginia. . & 600,000 & & 200,000 & & 800,000 \\
\hline III & Washington & 20,500 & & & & 20,500 \\
\hline & West Virg & & & 23,900 & $\mathrm{~mol}$ & 23,900 \\
\hline Ib & Wisconsin & $2,000,000$ & & & 000 & Wu \\
\hline & & $|52,665,020|$ & $6,826,019$ & $|14,747,805|$ & $4,766,179$ & 79,00 \\
\hline
\end{tabular}

* After Elliott, from Senate Document 443, 60th Congress, 1 Session 1908 the Abbreviations prefixed to the States are added by the writer to show the general regional divisions referred to in the text on p. 454. 
main points in connection with their bearing upon the stratigraphic relations of peat deposits in the United States and in Europe.

An account of the general features of peat deposits and a definition of the term will naturally differ according to the point of view. On the economic side, the features of fundamental importance are those which qualify a deposit as a resource of raw materials of value for fuel, for distillation purposes, for manufacturing various finished products, as medium for beneficial bacterial activity, or for use in other specific ways. To the geologist, the most striking feature lies in the fact that a peat deposit may be regarded as a portion of the earth's surface-layers which represent an initial stage in the formation of coal beds and petroleum.

On the agricultural side, a peatland area leads to the consideration of its characteristics as an organic soil which furnishes support and nourishment to cultivated plants, but is generally unbalanced in the supply of inorganic plant-food constituents. The features of chief importance to agricultural aspects are special methods of drainage, fertilizing, cultivation and suitable cropping systems with which to maintain the fertility of organic soils and to make them increasingly serviceable to the community as a source of food for man and cattle. But all of these viewpoints may be summed up in the biological concept which regards peat deposits as formed by the successive growth of vegetation units, which now constitute accumulations of more or less disintegrated plant remains. The different layers of peat material were laid down in a definite manner according to imposed field conditions. The efficient use of peat deposits, whether as an available resource for food, power or finished products depends in large part upon the kind of organic material, the structure of the deposit, and the controlling factors in field conditions. The feature of noteworthy significance is that a peat deposit and its field conditions are to be regarded as correlated with each other in development and structure, in time and space relations.

In general, it would be advantageous to adopt the word moor as a synomym for peat deposit. Both terms should be limited to an accumulation of plant remains of at least 8 to 10 inches in thickness when compact and well shrunk. In this accumulation, the surface layer of living native vegetation and deposits containing more than 40 per cent of mineral matter should not be included. This restriction of the term would prove useful for purposes of mapping, and it would make for precision in surveys, in methods of practice, in instrumental investigation, in correlation studies, and in that large and increasing line of inquiry that depends on experimental work at field stations located in representative peatland areas.

\section{CLASSIFICATION OF PEAT DEPOSITS}

In evaluating peatland areas it is important to adopt a standard for classifying the deposits. The need of some method of classifying areas of peatland is as obvious as in the case of peat material resources. 
Although classifications made by various investigators may differ widely because of the divergence in concept of the cause and factors controlling peat deposits and their uses, those differences become less pronounced as the development and structure of peat deposits becomes better known and as peatland problems are founded on scientific research in the field and in the technical laboratories, on which all applied work must ultimately be based.

While peat deposits may be grouped according to the practical "usage" point of view from which the subject is approached, that is, from the consideration of agriculture or the manufacturing industries, it becomes evident that a classification made for convenience or for reference to mode of utilization will be unsatisfactory in that it tends to inexactness and uncertainty. Unexpected difficulties in the control of the water-table due to springs, in the quantity of sulfur contamination, or from any other evidence brought out after more detailed field work or laboratory research may suddenly cause a deposit to lose much of its reputed practical value and place it in the nonproductive class. On the other hand, improvements in methods of utilization may again change greatly the value of the practical classification. Some deposits may be used in several ways while in others the material has only a limited possibility. The various uses for which peat materials are best adapted have been discussed in detail in former publications $(6,7)$. The progress of peatland agriculture and the expansion of peat industries depend for their success upon the kind of raw material used, and hence due care must be observed in the selection of a workable deposit. In its larger aspect the criterion for a judicious choice should not only be fundamental, but also in line with the essential processes which initiate, continue or modify and finally terminate the development and structure of an accumulation of peat materials. It may be difficult for the layman to apply ecological and stratigraphic principles and to work out the basic factors of field conditions; it may be cumbersome for peatland operators to determine the relative importance of climatic, geologic, vegetational and topographic influences, especially where it is not readily evident whether the most striking cause may not be the less important and significant one in limiting the possibilities of a peat deposit. Nevertheless the view seems well supported from past failures that in the utilization of peat deposits for one or more practical purposes the field conditions and the layers of peat material are controlling factors in a profitable industry, and that the life history of the deposit should be carefully considered by prospective producers.

\section{System of classifying peat deposits based on surface vegetation}

Various comprehensive studies and classifications of peat deposits in America and elsewhere have been made according to the surface vegetation. There need be no objection to such terms as marsh, fen, bog, heath, shrub, forest, which represent a well marked physiognomy of vegetation. They are common names in many languages and the field conditions of each have a more or 
less differentiating character, notably in the relation of the ground-water level to the surface of the soil. The possibility of using the native surface vegetation as a basis for differentiating between deposits of peat rests, however, entirely on the provision that the relation between the living vegetative cover, the character of the profile structure of the deposit, and the nature of the underlying mineral soil, is correctly interpreted. The degree of natural drainage which establishes itself in time on the surface of a deposit often determines the character of the vegetative cover. As a rule, deciduous trees such as maple, ash, elm and others are looked upon to indicate a better quality of deposit but exceptions are not uncommon where the material on which grow tamarack, spruce, or cedar would yield better results. The accumulation of vegetable material in the layer just below the surface vegetation is by far more frequently the decisive factor on reclaimed peat deposits, and hence of greater significance than the thin veneer of material formed from the plants on the surface of abandoned peat deposits or in consequence of fire or drainage.

There are few deposits which have not some kind of a structure formed during the various periods of time when the peat materials were deposited. In dealing with surface vegetation alone as an indicator, it would be impossible to determine the extent to which the vegetative cover is a characteristic of that structure or whether it was at all times successively the top layer at that point. A clearer concept will be gained in regard to the value of surface vegetation for distinction between peat deposits when accumulations of peat are considered in the light of their origin. Continuous deposition of a peat material from any type of surface vegetation would produce a deposit nearly uniform throughout, provided the field conditions remained constantly the same; the thickness of accumulation would be commensurate with the rate of deposition, the length of time and the nature of the plant remains. Variation in the composition or in the nature of the vegetation unit forming peat, or a change in field condition would bring about a commensurate change in the character of the deposit. The great changes in the stratigraphic features of peat deposits may safely be regarded as indicative of major changes in the surface vegetation at that particular time, and in the field conditions during that period. There are deposits in which the course of development has been a conversion of forest to marsh and finally to open water, and there are others the structure of which shows alternations between or different combinations in the superposition of several types of peat material. The occurrence of sedimentation, for example clay and sand from floods or from subsidence, as intercalations between layers of peat, serves to qualify very markedly any relationship between surface vegetation and the character of the deposit. It is necessary to bear in mind that by itself a surface vegetation of any unstable stage in the formation of peat deposits can not be regarded as significant in the determination of groups, classes, or other divisions of peatland areas. As a rule, the present plant populations at the surface, many of which have been described and classified elsewhere $(4,6)$ enter but little into the structure 
of the larger portion of a deposit. The older or lower layers of peat deposits of the Scandinavian countries, of Holland, Germany, Switzerland, Finland and Russia, have a surprising number of features in common with some of the peat deposits in this country. With further accumulation of plant remains this feature becomes less marked; those of the regional distribution of plants and of climatic differences gradually increase in effectiveness. In surface vegetation of today many American and European deposits are quite unlike.

\section{Topographic classification of peat deposits}

There are peat deposits which are obviously associated with topographic conditions. They represent filled lakes and ponds, accumulations within and between moraines, on till plains and other flat areas and combinations of these types of land surface. However, in another paper dealing separately with representative groups of peat deposits, it will be possible to indicate that many of them are far from showing an exclusive relation to topographic conditions. These deposits comprise accumulations of plant remains in ancient drainage channels, glacial lake basins, old wave-built terraces or plains bordering the ocean and other important land forms which in all cases were free from water when marsh, forest and other vegetation units began to occupy these areas. They are among the chief sites of peat accumulations of the present time. Furthermore, the present streams and smaller drainage channels of peat lands are as a rule very young, having been established in most cases subsequent to the formation of the peat deposits. Most of the waters now flow on top of several layers of peat material and in places flow over deposits in which they are forming new and more or less distant channels. The imperfections of the surface drainage, shown by that large acreage of so-called swampy, overflowed, and wet grazing lands, is due in great measure to the comparative shortness of time since the establishment of the present surface streams and the retardation consequent on vegetation obstructing the run-off.

It is a striking fact that in the past far-reaching vegetation changes appear to have taken place over a great variety of land forms and, in many cases, without any marked correlation on the part of any factor except the water relation. The underlying causes for many vegetation changes even of today are found more readily in the successions of plant populations which operate within the limits of the controlling climatic factor of the region concerned. But the chief objection to a primary classification of peat deposits on topographic differences is that it obscures the structural development of a deposit and adds to the difficulty of distinguishing peatland areas which result from a rise in the water level through barrier formation, from flooding due to increased rainfall, from subsidence of a region or other disturbances. Moreover, certain soil conditions may arrest the succession of vegetation and keep it stationary at a point far short of the possible development within the topography of the area, while elsewhere the influence of plant migration and 
of regional differences in vegetation increases in effectiveness. It appears probable and in fact seems a necessary consequence of the direct and inferential evidences obtained by Swedish investigators during the past decade that the character and direction of the structural formation of a peat deposit depends more upon climatic changes than upon anything else.

\section{European system of classifying peat deposits}

The classification of peat deposits which resulted from European investigations has reference to the sequence or superposition of certain types of peat material found in the moors. Three kinds of deposits or moors are recognized as main stages of a developmental series (22); low moor or flat moor (Niedermoor, Flachmoor, Verlandungsmoor) the vegetation units of which give rise to the marsh group of peat materials; transition moor or intermediate moor (Zwischenmoor, Ubergangsmoor) from which shrub and forest types of peat are derived, and highmoor (Hochmoor) which in the main is equivalent to sphagnum and heath types of peat. The tendency of some authors is to eliminate the transition moor since it appears to be less well characterized than the low moor and the high moor. The differences between the two latter in botanical composition of plant remains are well marked and they serve primarily for estimating the agricultural and industrial possibilities of these deposits. But the existence of upper and lower forest beds in peat land, found at the same horizon through deposits in widely separated regions, is of relatively great scientific importance. Shrub and forest types of peat indicate evidence, it is believed, for considerable changes in the environment during late glacial and postglacial times, and in the migration of vegetation. That peat deposits will yield abundant information on these points may be expected from the results already obtained in Europe by De Geer and Sernander (9), von Post (15), Samuelsson (17), Weber (22) and others.

The European system embodies the results of prolonged consideration and is well adapted to delineate the pronounced climatic influences of the northern part of that continent. But the continental system of classifying peat deposits is too limited for satisfactory discriminations in other countries. It is not suitable to peatland areas of other climates and to those deposits which upon examination show that other kinds of developmental and structural features are possible than those illustrated by the relative position of high-moor peat materials resting on low-moor types of plant remains. The striking crosssections of American peat deposits such as the Kankakee marsh in Indiana, the Everglades of Florida, or the Dismal Swamp in Virginia and North Carolina are typical examples of what may be expected in the space and time relations of other kinds of peat deposits. They give a significant interest to investigations and to experimental work of peat deposits elsewhere which were formed under climatic influences quite unlike those of northern continental regions. 


\section{Classification of peat deposits based on chemical analyses}

A distinction is often made between peat deposits on the basis of chemical differences, especially in lime content or in acid reaction. These and other chemical distinctions are unreliable when not related to type of peat material and they are inadequate to be used for purposes of classifying peat deposits. Chemical analyses are difficult to interpret and they are practically worthless when a peat deposit consists of a series of different layers of peat, and especially so when some of these are separated by intercalated mineral sediments, or contain siliceous, sulfureous or ferruginous material as contaminations or as depositions by plants and animals. Cases of that kind are numerous in deposits of peat near rivers and subject to overflow.

In the greater number of deposits a low content of lime or other mineral constitutents may be regarded as due partly to the underlying soil and geologic formation. A clay or marl substratum usually indicates fertilizer requirements quite different from sandy subsoils. Differences in quantity and in quality of salt content become observable as a rule after drainage, and under cropping systems which favor evaporation of the ground water from the surface layer of the organic soil. These conditions may affect all kinds of deposits alike when they are under cultivation and shrink. It is important to note that the influence of capillary action upon salt solutions, which Briggs and Lapham (2) have investigated, is related also to capillary limits in types of peat, and that studies on absorption and differential deposition, like those of Cameron (3) and of Patten and Waggaman (14), should be carried out on peatland areas before a chemical or a fertilizer analysis may be of value in differentiating between peat deposits. The fact should not be overlooked that layers of peat at different levels or the removal of surface material may give rise to entirely different chemical reactions.

The physical and chemical changes which take place in peat deposits are brought about to some extent by micro-organisms. Their presence in peat

- deposits has been demonstrated by a number of investigators (11). Some of the chemical reactions in bacterial culture studies with several types of peat have been reported in an earlier work (6) in connection also with the problem of bacterial by-products in peat deposits, contributing to the xeromorphy in the vegetation of the coal age (5). Results secured in Europe and in this country indicate that requirements of chemical fertilizers are often for the purpose of balancing products due to bacterial activity, for example, an excess of available nitrogen. Green plants on peat deposits utilize water and the carbon dioxide to form food, the starches, sugars and fats necessary to their nourishment. The mineral soil constituents are indispensable, but their amount is very small for any native vegetation unit growing on peat deposits and alone the inorganic salts are incapable of sustaining life in plants.

It is obvious, therefore, that a chemical classification of peat deposits based on initial tests or requirements must differ considerably from one made at a 
later period and it is apparent also that it would be in general easier to remedy the chemical deficiences than to change the nature and characteristic influence of the type of peat material or the structure of the deposit.

The stratigraphic system of classifying peat deposits

In a system of classifying peat deposits which is to conform with the development and structure of such deposits, it is clear that the genesis and sequence of peat materials must constitute the chief basis for grouping; it must furnish basic criteria concerning the causes and methods by which the structural features, changes and conditions have been produced or can be utilized. A stratigraphic classification of peat deposits such as the writer proposes thus includes more especially the two great primary divisions of water-laid and land-laid peat deposits, the latter of which show as the noteworthy characteristic the presence of roots in the mineral substratum. This system necessarily includes and is based upon a botanical analysis of the peat materials themselves, of their sequence and relative position. It represents the historical and genetic view in its broader sense, deals with the structural features which deposits exhibit and, furthermore, takes careful account of the past physical conditions of the environment. Nor does it leave out of consideration, the various regional and climatic changes and their influence during the entire period in which the deposits were formed. The botanical composition of peat materials, their successional position in a deposit, the habitat conditions which they reflect, all have their importance but their chief value lies in correlations and in pointing out the basic process by which a peat deposit arises and culminates, becomes stabilized or converted. A peat deposit undergoes changes in structure until it comes into equilibrium with environmental conditions and thereupon continues without further change in structure. Whenever the conditions are changed climatically, physiographically, by migration or alteration in plant and animal populations, a corresponding change of structure results. But this change does not necessarily imply advance. Often it is towards neither a progressive nor retrogressive structure, but a new combination, a complex or mosaic which spreads upon and supplants the earlier structural features. In the light of the stratigraphic results obtained it should not be difficult to find out to what extent the life history of the various deposits is essentially the same or presents striking differences. More complete studies, of course, will contrast these differences, and they will soon furnish a more correct insight. Those who are cognisant of the meaning of these facts from an economic as well as a scientific point of view will be able to realize how important and urgent is the need for looking more fully than heretofore into the structural features of peat deposits and not only of investigating the main types of peat material but also of obtaining a further measure of technical and mechanical utilization of these stores of accumulated energy.

The fundamental problem in a stratigraphic or developmental classification of peat deposits is, however, not alone the local sequence of types of peat 
material, but also the equivalence of these types in different geographical regions. If principles and processes are of universal application, it is important to know to what extent the layers of one deposit may constitute a natural group strictly homologous in its age or time relation, with all the layers of a similar deposit elsewhere. The establishment of likenesses and differences among peat deposits, and of a time relationship between peat deposits of separate morainal systems and of different regions has not been as yet among the aims of American workers in peat problems. The work of foreign investigators, though familiar to the specialist, has generally escaped the attention of the student. Hence it has not been possible hitherto to contribute either toward establishing the identity and corresponderice or to determine the exact time equivalence of peat deposits of great recessional moraines and between different countries. There appears to be little doubt that the identification of layers of peat material by means of the plant remains included in them will make feasible a grouping of deposits which formed during a common substage in the glacial period, and which may thus be referred to or based on a general age and time scale.

The period of the Wisconsin stage of glaciation was not a single advance and melting of the ice sheet but was somewhat complex. The early stage of the retreat of the ice sheet, which was marked by the Shelbyville and the Bloomington morainic systems, appears to have been followed by a readvance of the ice and by a shifting of the line of flow as the ice again spread out over the surface of the land. This readvance has been designated as the later Wisconsin stage. The limit of the readvance is marked by the ValparaisoKalamazoo-Mississinewa morainic systems.

The stratigraphic study and the mapping of peat deposits distributed within the series of important positions of the ice border as the result of the melting of the glaciers, may furnish valuable data for the study of past climatic changes. The various morainic groups, such as the Shelbyville, the Bloomington, the Valparaiso-Kalamazoo-Mississinewa, the Lake Border-Defiance, and the Port Huron morainic system represent climatic pulsations. They mark halting places during which the climate ceased to become milder and either remained nearly uniform for a while or else reverted somewhat toward the conditions which induce glaciation. It is obvious, therefore, that the sequence of peat materials in the deposits of these main systems may furnish the data for characterizing the climate of the earlier and the later Wisconsin stages and of the successively less extensive portions of the ice front. Perhaps a further classification of the peat deposits of the United States into two main subdivisions-those beyond the invasion of the late Pleistocene ice age and those within the glaciated area of the country would prove more practical. The minor subdivisions, especially of the deposits relating to the successive positions of the ice border, might give a record of striking individuality. They outline areas over which may exist similar advantageous types of peat, and they may give much information regarding suitable deposits for experimental work in agricultural and industrial problems. 
Many of the European workers refer the stratification of a peat deposit not to successive changes in the level of ground water but correlate the sequence of peat materials with alternating wet and dry periods which accompanied changes in climatic conditions. It will now be possible to extend the European investigations dealing with climatic changes to the glacial regions of North America and to show whether or not glaciations have been contemporaneous, whether they depended upon general or local causes, and whether plant populations have immigrated and were affected by alternating dry and humid periods. But until the plant remains in peat deposits are more extensively studied microscopically and along lines of modern investigations, as those of Lennart von Post (16) and his collaborators, similarity of sequence and resemblance of types of peat material will be taken as the criterion. The procedure may lead to many erroneous correlations. Correspondence in succession of peat materials cannot always be regarded to have significance in regard to time equivalence as well, for example, in those cases where the layer of peat of the same botanical character is not necessarily of the same age, or where deposits of the same geologic period may contain plant remains not at all of the same botanical composition.

It is thus seen that a classification based on stratification soon must take on a chronologic aspect, especially as workers in peat problems begin to perceive that only a limited number of peat materials may be formed during the lifetime of a deposit and that in some areas the strata are often separated from those above them by a sharp line of demarkation. For the detailed study of American peat deposits correlation by plant remains is undoubtedly the most reliable working method and to identify the chief groups of American types of peat with similar types in other countries may be, in many cases, not far from wrong. There is little doubt that the morphological basis of classifying peat deposits will gain in value when established on renewed and thorough microscopic study and methods such as those used, for example, by the "Upsala School" $(9,13,16,18,19)$. It is equally evident that the study of American peat deposits must be pursued independently if the growing demands of peatland industries and agriculture are to receive adequate scientific coöperation.

\section{REFERENCES}

(1) BAKER, O. E., AND Strong, H. M. 1918 Arable land in the United States. In U. S. Dept. Agr. Yearb. 1918, p. 433-441.

(2) Briggs, L. J., and Lapham, M. H. 1902 Capillary studies. U. S. Dept. Agr. Bur. Soils Bul. 19.

(3) Cameron, F. K. 1906 Calcium sulphate in aqueous solutions. U. S. Dept. Agr. Bur. Soils Bul. 33.

(4) Clements, F. E. 1916 Plant succession: An analysis of the development of vegetation. Carnegie Inst. Washington Pub. 242.

(5) Dacenowski, A. P. 1911 The problem of xeromorphy in the vegetation of the carboniferous period. In Amer. Jour. Sci., v. 32, p. 33-39. 
(6) Dachnowski, A. P. 1912 Peat deposits of Ohio. Ohio Geol. Survey Bul. 16, p. 4. (In cooperation with U. S. Bur. Mines.)

(7) DAChnowskr, A. P. 1919 Quality and value of important types of peat material. U. S. Dept. Agr. Bur. Plant Indus. Bul. 802.

(8) Davis, C. A. 1912 The uses of peat for fuel and other purposes. U. S. Bur. Mines Bul. 16.

(9) DeGeer, G., AND Sernander, R. 1908 On the evidences of late quaternary changes of climate in Scandinavia. In Geol. Förening. Förhandl., v. 30, p. 457-478.

(10) Development of unused lands. House Doc. No. 262, 66th Congress, 1st Session, 1919.

(11) LöHNIs, F. 1910 Handbuch der landwirtschaftlichen Bakteriologie. Berlin.

(12) MCCRory, S. H. 1918 The drainage movement in the United States. In U. S. Dept. Agr. Yearb. 1918, p. 137-144.

(13) OdEN, S. 1920 Bodenkundlische Forschungen an dem chemischen UniversitätsLaboratorium der Universitat Uppsala, 1914-1919. In Internat. Mitt. Bodenk., Bd. 9, p. 391-418.

(14) Patton, H. E., and Waggeman, W. H. 1906 Absorption by soils. U. S. Dept. Agr. Bur. Soils Bul. 52.

(15) Post, L. von 1909 Stratigraphische Studien tber einige Torfmoore in Nurke. In Geol. Förening. Förlandl., Bd. 31, p. 629-706.

(16) Post, L. voN 1916 Skogsträdpollen i sydsvenska torfmosslagerföljder. In Geol. Förening. Förhandl., v. 38, p. 384-390. Complete report in Förhandl. Skand. Naturf. Mote, p. 433-465. 1918.

(17) Samuelsson, G. 1910 Scottish peat mosses: A contribution to the knowledge of the late-quaternary vegetation and climate of northwestern Europe. Bul. Geol. Inst. Univ. Upsala, v. 10, p. 197-260.

(18) Sandegren, R. 1916 Homborgasjön en monografisk framställning av dess postglaciala utvecklings-historia. In Sveriges Geol. Undersökn., Ser. Ca. No. 14.

(19) Sernander, R. 1908 Om ancylustidens människa och tall-perioden i södra Skandinavien. In Geol. Förening. Förhandl., v. 30, p. 388-398.

(20) Swamp lands of the United States. Senate Doc. No. 443, 60th Congress, 1st session, 1908.

(21) Wright, J. O. 1907 Swamp and overflowed lands in the United States. U. S. Dept. Agr. Off. Exp. Sta. Cir. 76.

(22) Weber, C. A. 1910 Was lehrt der Aufbau der Moore Norddeutschlands uber den Wechsel des Klimas in postglazialer Zeit? In Ztschr. Deut. Geol. Gesell., Bd. 62 (1911), Heft. 2, p. 143-162. 